\title{
Penerapan Pembelajaran Kontekstual Untuk Meningkatkan Hasil Belajar IPA
}

\author{
I Ketut Ngurah Diatmika1* \\ Sekolah Dasar Negeri 1 Ban
}

A R T I C L E I N F O

Article history:

Received 20 August 2018

Received in revised form 9 September 2018

Accepted 15 October 2018

Available online 25

November Februari 2018

\section{Kata Kunci:}

Pembelajaran Kontekstual

dan Hasil Belajar IPA

Keywords:

Contextual Learning and Science Learning Outcomes.

\begin{abstract}
A B S T RAK
Penelitian ini dilaksanakan di Sekolah Dasar Negeri 1 Ban di kelas IV Semester I tahun Pelajaran 2016/2017 yang hasil belajar pada mata pelajaran IPA masih rendah. Penelitian ini bertujuan untuk mengetahui apakah penerapan pembelajaran kontekstual pada pelajaran IPA dapat meningkatkan hasil belajar. metode pengumpulan data adalah dengan tes hasil belajar. Metode analisis datanya adalah analisis kuantitatif terhadap hasil tes evaluasi belajar siswa. Hasil penelitian menunjukkan bahwa penerapan model pembelajaran kontekstual dapat meningkatkan hasil belajar IPA siswa. Peningkatan hasil belajar tersebut dapat dilihat dari perolehan nilai rata-rata, daya serap, dan ketuntasan belajar klasikal. Nilai rata-rata hasil belajar pada refleksi awal sebesar 64,82 menjadi 70,00 pada siklus I dengan peningkatan sebesar 5,18. Sedangkan pada siklus II mengalami peningkatan sebesar 5,89 menjadi 75,89. Peningkatan juga terjadi pada daya serap dan ketuntasan belajar klasikal. Pada refleksi awal daya serap tercapai sebesar $64,82 \%$ selanjutnya pada siklus I meningkat menjadi $70,00 \%$. Hal yang sama juga terjadi pada siklus II dengan daya
\end{abstract} serap mencapai $75,89 \%$. Sedangkan ketuntasan belajar klasikal pada refleksi awal sebesar $25 \%$ kemudian meningkat menjadi $53,57 \%$ pada siklus I dan menjadi $92,86 \%$ pada siklus II. Kesimpulan yang diperoleh dari penelitian ini adalah penerapan pembelajaran kontekstual mampu meningkatkan hasil belajar IPA SD Negeri 1 Ban kelas IV Semester I tahun pelajaran 2016/2017.

\section{A B S T R A C T}

This research was conducted at Sekolah Dasar Negeri 1 Ban in class IV of the first semester of Academic Year 2016/2017 where the learning outcomes in science subjects were still low. The study aims to determine whether the application of contextual learning in science lesson can improve the learning outcomes. The method of collecting data is by learning outcomes tests. The method of data analysis is quantitative analysis of the results of student learning evaluation tests. The results of the study indicate that the application of the contextual learning model can improve students' science learning outcomes. The increase in learning outcomes can be seen from the average values of acquisition, absorption, and the completeness of classical learning. The average value of learning outcomes in the initial reflection is 64.82 to 70.00 in the first cycle with an increase of 5.18. While in the second cycle increased by 5.89 to 75.89. The increases also occur in the absorption and completeness of classical learning. On the initial reflection, absorption was achieved at $64.82 \%$. Moreover, in the first cycle, it increased to $70.00 \%$. The same thing happened in the second cycle with absorption reaching $75.89 \%$. While classical learning completeness at the initial reflection is $25 \%$ then increases to $53.57 \%$ in the first cycle and becomes $92.86 \%$ in the second cycle. In this study, it can be concluded that the application of contextual learning is able to improve learning outcomes of Natural Sciences 1 Elementary School Ban class IV Semester I 2016/2017 academic year. 


\section{Pendahuluan}

Pendidikan merupakan bagian integral dalam pembangunan. Proses pendidikan tak dapat dipisahkan dari proses pembangunan itu sendiri pembangunan diarahkan dan dan bertujuan untuk mengembangkan sumber daya yang berkualitas. Manusia yang berkualitas dapat dilihat dari segi pendidikan. Hal ini terkandung dalam tujuan pendidikan nasional, bahwa pendidikan nasional bertujuan untuk mencerdaskan kehidupan bangsa dan mengembangkan manusia seutuhnya, selain beriman , bertakwa pada tuhan Yang Maha esa serta sehat jasmani dan rohani, juga memiliki kemampuan dan keterampilan.

Muatan yang ada dalam KTSP adalah meliputi berbagai pelajaran salah satunya IPA. Pembelajaran IPA menyesuaikan dengan karakteristik dan kemampuan siswa. Siswa mempunyai kemampuan yang berbeda-beda dalam satu kelas, ada yang pandai, sedang, dan ada yang kurang. Perbedaan kemampuan mempengaruhi siswa untuk menguasai konsep-konsep IPA. Penguasaan konsep IPA siswa juga dipengaruhi oleh gaya mengajar guru di kelas. Kenyataan yang terjadi mata pelajaran IPA tidak begitu diminati dan kurang disukai oleh siswa. Bahkan siswa beranggapan mata pelajaran IPA sulit untuk dipelajari. Akibatnya rata-rata hasil belajar siswa cenderung lebih rendah dibanding mata pelajaran yang lainnya. Pada data awal hasil belajar IPA siswa kelas IV di semester I tahun pelajaran 2016/2017 di SD Negeri 1 Ban baru mencapai nilai rata-rata 64,82

Untuk itu sebagai salah satu komponen yang sangat penting dalam meningkatkan kualitas pendidikan, kegiatan belajar mengajar perlu dirancang agar mampu meningkatkan pemahaman konsep yang bermuara pada hasil belajar siswa serta sejalan dengan tuntutan Kurikulum Tingkat Satuan Pendidikan. Untuk menggali potensi anak agar selalu kreatif dan berkembang perlu diterapkan pembelajaran bermakna yang akan membawa siswa pada pengalaman belajar yang mengesankan. Pengalaman yang diperoleh siswa makin berkesan apabila proses pembelajaran yang diperoleh merupakan hasil dari pemahaman dan penemuannya sendiri yaitu proses yang melibatkan siswa sepenuhnya untuk merumuskan suatu konsep. Untuk itu sudah menjadi tugas guru dalam mengelola proses belajar mengajar adalah memilih model pembelajaran yang sesuai, agar pembelajaran lebih menarik dan bermakna. Apabila guru betul-betul menguasai dan mengerti tentang hal-hal tersebut dapat diyakini bahwa hasil belajar peserta didik pada mata pelajaran Ilmu Pengetahuan Alam tidak akan rendah.

Melihat kenyataan diatas penulis melakukan melakukan upaya perbaikan pembelajaran dengan menggunakan penerapan pembelajaran kontekstual pada mata pelajaran IPA. Pemilihan penerapan pembelajaran kontekstual ini sebagai salah satu alternatif model pembelajaran yang bermuara pada pembelajaran yang aktif, kreatif, efektif dan menyenangkan. Blanchard, Berns dan Erikson, (dalam Komalasari, 2010:6) mengemukakan bahwa pembelajaran kontekstual merupakan konsep belajar yang membantu guru mengaitkan antara materi yang diajarkan dengan situasi nyata siswa dan mendorong siswa membuat hubungan antara pengetahuan yang dimilikinya dengan penerapannya dalam kehidupan mereka sebagai anggota keluarga, dan masyarakat. Model pembelajaran kontekstual mampu menciptakan pembelajaran yang lebih bermakna dalam membangun konsep pada siswa sehingga lebih mudah diingat dan diimplementasikan dalam kehidupan sehari-hari. Oleh karenanya penelitian ini sangat penting untuk dilaksanakan.

\section{Metode}

Jenis penelitian yang digunakan adalah Penelitian Tindakan Kelas. Untuk mengumpulkan hasil belajar siswa seperti yang diharapkan adalah dengan menggunakan tes evaluasi hasil belajar. Adapun data hasil penelitian ini yang dipergunakan dalam menganalisis tingkat keberhasilan belajar dengan metode analisis deskriftif kuantittif. Data kuantitatif dianalisis dengan mencari rata-rata(mean), daya serap, dan ketuntasan klasikal belajar serta menyajikan dalam bentuk tabel dan grafik. Indikator keberhasilan penelitian yang diusulkan dalam penelitian ini pada siklus I mencapai nilai rata-rata 70 dengan daya serap $70 \%$ serta ketuntasan belajar klasikalnya $75 \%$ dan pada siklus II mencapai rata-rata 70 atau lebih, daya serap 70\% atau lebih serta ketuntasan belajar klasikla minimal 75\%. Yang dijadikan lokasi penelitian adalah SD Negeri 1 Ban. Sekolah ini berada di pedesaan yang cukup kondusif dalam proses pembelajaran. Bagaimana pelaksanaan penelitian ini dapat dilihat pada Gambar 1 berikut:

Pelaksanaan penelitian tindakan kelas ini mempergunakan rancangan dari Suharsimi Arkunto 


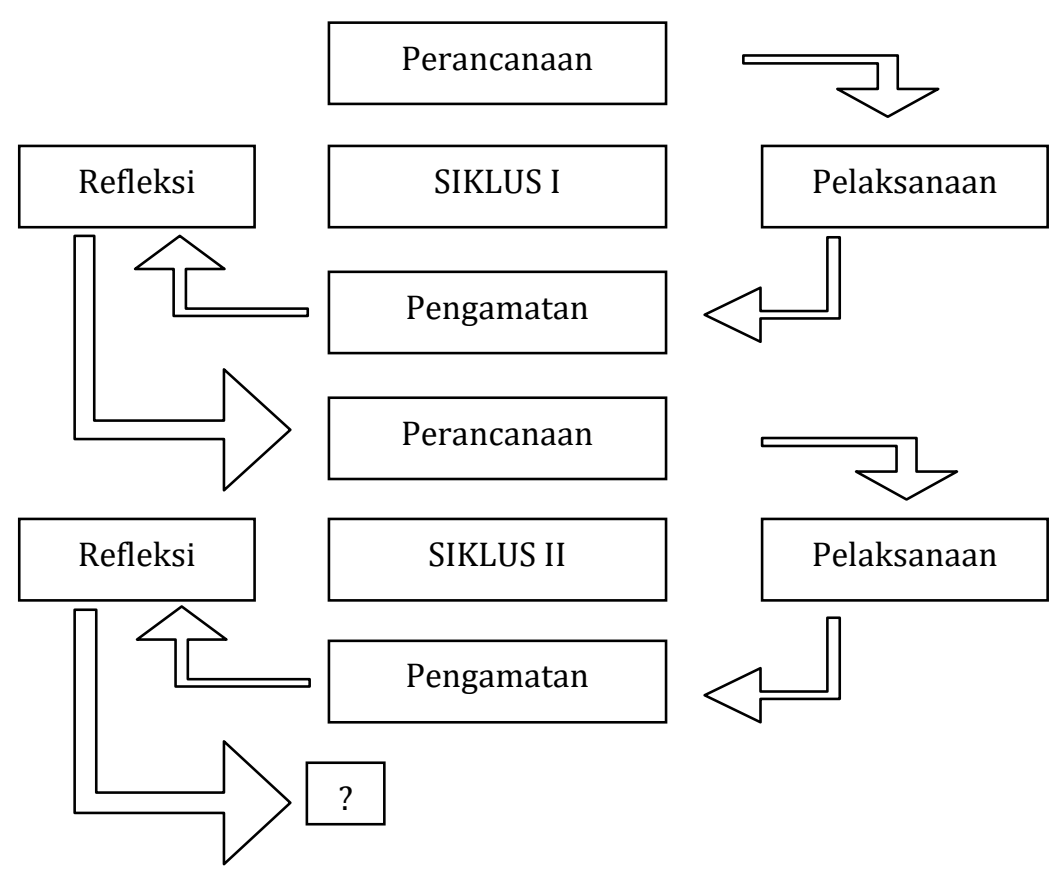

Gambar 1. Penelitian Tindakan Kelas Model Suharsimi Arikunto, 2009

Pelaksanaanya di kelas sesuai gambar di atas, adalah penelitian didahului dengan perencanaan, pelaksanaan tindakan , observasi dan evaluasi serta refleksi. Hasil refleksi digunakan sebagai perencanaan dan tindakan selanjutnya sehingga memebentuk sebuah siklus pembelajaran. Pada penelitian ini siklus digunakan untuk mengetahui tingkat keberhasilan suatu proses pembelajaran dan digunakan dalam memperbaiki proses pembelajaran yang telah dilakukan sebelumnya. Penelitian ini mengambil subjek penelitian yaitu siswa kelas IV SD Negeri 1 Ban Semester I tahun pelajaran 2016/2017. Objek dari penelitian ini adalah peningkatan hasil belajar IPA siswa kelas IV SD Negeri 1 Ban semester I tahun pelajaran 2016/2017 setelah diterapkan model pembelajaran kontekstual.

\section{Hasil dan Pembahasan}

Tindakan yang dilakukan dalam penelitian ini adalah kegiatan untuk meningkatkan hasil belajar Ilmu Pengetahuan Alam (IPA) siswa kelas IV SD Negeri 1 Ban semester I tahun pelajaran 2016/2017. Setelah data diperoleh, selanjutnya disampaikan deskripsi yang lengkap terhadap apa yang telah dilakukan baik dalam perencanaan, pelaksanaan, observasi dan refleksi. Dalam refeksi dilakukan analisis yaitu analisiskuantitatif. Analisis kuantitatif dilkukan sehubungan dengan data yang dihasilkan adalah data berbentuk angka.

Siklus I terdiri dari empat tahapan yaitu tahapan pertama adalah perencanaan tindakan I, langkahlangkah dalam perencanaan tindakan ini yaitu, a)Menyususn RPP dengan menggunakan penerapan pembelajaran kontekstual yang dapat dilihat pada lampiran, b) Menyiapakan alat/bahan dan media yang sesuai dengan skenario pembelajaran yang disusun, c) Menyiapkan LKS sesuai dengan materi yang akan diajarakan, d) Menyiapkan instrumen evaluasi hasil belajar dalam bentuk tes tertulis, e) Membuat lembar observasi aktifitas belajar siswa, f) Menetapkan hari dan tanggal pelaksanaan yang terdiri dari 2 kali kegiatan pembelajaran. Pada tahap II pelaksanaan tindakan pada siklus I terdiri dari kegiatan yang terangkum dibawah ini yaitu : Kegiatan awal yang meliputi apersepsi dan pengelolaan kelas, menyiapkan materi ajar secara matang, menjelaskan kegiatan yang akan dilaksanakan sesuai skenario pembelajaran yang telah disusun, mengorganisaikan siswa dalam kelompok belajar untuk berdiskusi, tanya jawab , memfasilitasi kegiatan siswa dengan menyiapkan LKS yang digunakan dalam kerja kelompok untuk melaksanakan pengamatan terhadap materi yang diajarkan di lingkungan sekolah, hasil kerja kelompok didiskusikan dengan kelompok yang lain sertapada kegiatan akhir mengadakan evaluasi hasil belajar dengan tes terulis yang sudah disusun. Pada tahap III ,dari siklus I adalah observasi terhadap hasil tindakan yang telah dilaksanakan. Hasil tes hasil belajar yang diperoleh dari pelaksanaan tindakan ditunjukkan pada Tabel 1. 
Tabel 1. Hasil belajar IPA siswa kelas IV SD Negeri 1 Ban Semester I Tahun pelajaran 2016/2017 siklus I

\begin{tabular}{|c|c|c|c|c|}
\hline $\begin{array}{c}\text { Nomor Subjek } \\
\text { Penelitian }\end{array}$ & NAMA SISWA & NIS & NILAI & KETERANGAN \\
\hline 1 & I Nyoman Reda & 1662 & 65 & Belum Tuntas \\
\hline 2 & Ni Komang Rustiana Dewi & 1726 & 70 & Tuntas \\
\hline 3 & I Ketut Arya Linjong & 1748 & 65 & Belum Tuntas \\
\hline 4 & I Komang Widiantara Putra & 1827 & 65 & Belum Tuntas \\
\hline 5 & I Kadek Wirawan & 1829 & 75 & Tuntas \\
\hline 6 & Ni Wayan Apriyanti & 1830 & 75 & Tuntas \\
\hline 7 & I Komang Alit & 1831 & 65 & Belum Tuntas \\
\hline 8 & I Made Toni Angga Sukma & 1838 & 80 & Tuntas \\
\hline 9 & Pande Kadek Ristayani & 1839 & 80 & Tuntas \\
\hline 10 & Ni luh Susiani & 1840 & 75 & Tuntas \\
\hline 11 & I Komang Ari Sudiarsana & 1842 & 80 & Tuntas \\
\hline 12 & Ni Nengah Julita & 1844 & 75 & Tuntas \\
\hline 13 & Ni Kadek Eva Antari & 1846 & 75 & Tuntas \\
\hline 14 & I Ketut Dedy Rustyawan & 1847 & 70 & Tuntas \\
\hline 15 & I Nengah Putu Yoga Pratama & 1849 & 70 & Tuntas \\
\hline 16 & I Nengah Mario & 1851 & 65 & Belum Tuntas \\
\hline 17 & I Komang Aditya & 1857 & 65 & Belum Tuntas \\
\hline 18 & I Komang Feri Sastrawan & 1859 & 75 & Tuntas \\
\hline 19 & Ni Komang Novi Widiastuti & 1863 & 70 & Tuntas \\
\hline 20 & Ni Luh Era Prasetia & 1864 & 65 & Belum Tuntas \\
\hline 21 & I Komang Ari Kamis & 1868 & 65 & Belum Tuntas \\
\hline 22 & I Nengah Ari Arnawa & 1869 & 65 & Belum Tuntas \\
\hline 23 & Ni Komang Meliani & 1938 & 75 & Tuntas \\
\hline 24 & Ni Komang Erawati & 1796 & 70 & Tuntas \\
\hline 25 & Ni Komang Indrayani & 1798 & 65 & Belum Tuntas \\
\hline 26 & Ni Nyoman Tri Utami & 1812 & 65 & Belum Tuntas \\
\hline 27 & I Made Subawa & 1871 & 65 & Belum Tuntas \\
\hline 28 & I Wayan Wartana & 1873 & 65 & Belum Tuntas \\
\hline \multicolumn{5}{|c|}{ Jumlah } \\
\hline & Nilai rata-rata & \multicolumn{3}{|c|}{70,00} \\
\hline & Daya Serap & \multicolumn{3}{|c|}{$70,00 \% \%$} \\
\hline & Ketuntasan Klasikal & \multicolumn{3}{|c|}{$53,57 \%$} \\
\hline & KKM & \multicolumn{3}{|c|}{70,00} \\
\hline
\end{tabular}

Pada tahap III, yaitu refleksi siklus I, data yang diperoleh selama melaksanakan penelitian merupakan data dari Rata-rata hasil belajar siswa sesuai tabel di atas dihitung dengan menggunakan rumus yang telah ditetapkan. Data tersebut dapat disajikan dalam grafik dibawah ini. Penyajian dalam bentuk grafik dapat dilihat di bawah ini. 


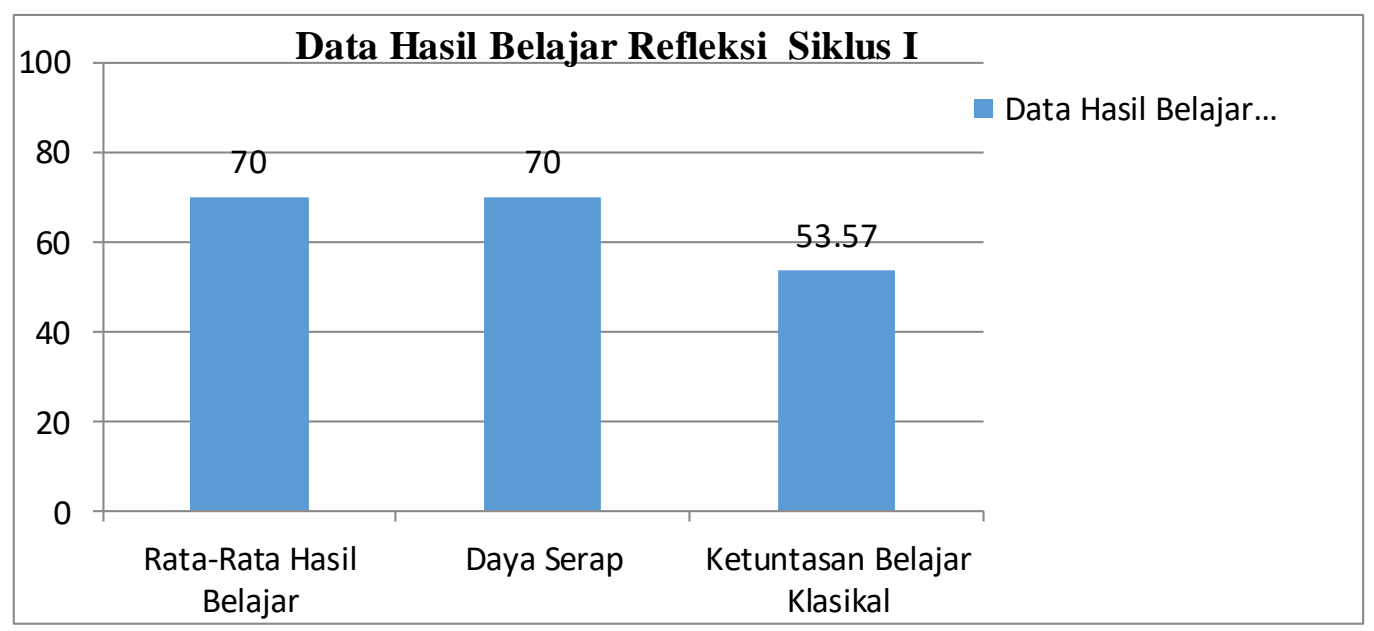

Gambar 2. Grafik Hasil Belajar IPA Siswa Kelas IV SD Negeri 1 Ban Semester I Tahun Pelajaran 2016/2017 Siklus I

Berdasarkan hasil analisis dalam tabel di atas diketahui bahwa secara klasikal siswa kelas IV SD Negeri 1 Ban sudah mampu mencapai target KKM yang ditetapkan pada mata pelajaran IPA. Rata-rata hasil belajar klasikal pada siklus I sebesar 70,00. Ini menunjukkan bahwa hasil tersebut telah sesuai dengan KKM yang besarnya 70,00 .Daya Serapa sudah mencapai 70,00\%. Pada sisi yang lainnya target ketuntasan belajar secara klasikal belum sesuai dengan harapan yaitu $75 \%$, target baru tercapai sebesar $53,57 \%$ yang ditunjukkan dengan jumlah siswa yang tuntas sebanyak 15 orang dan belum tuntas sebanyak 13 orang.

Keberhasilan yang digambarkan mengenai peningkatan nilai rata-rata dari data awal ke siklus I ternyata belum memenuhi indikator pencapaian keberhasilan penelitian yang diharapkan. Dari kajian yang dilakukan kemungkinan guru dan siswa belum terbiasa melaksanakan proses pembelajaran model kotekstual sehingga dari manajemen waktu dan perencanaan serta pelaksanaan masih belum sesuai dengan yang diharapkan. Siswa yang terbiasa dengan metode konvensional masih merasa sulit untuk menerima model yang baru yang walaupun dari hasil belajar yang diperoleh sudah ada peningkatan. Guru perlu menguasai lebih baik model pembelajaran yang telah direncanakan dan dalam pelaksanaannya dapat lebih ditingkatkan lagi baik dari manajemen waktu, materi, pelaksanaan dan evaluasi yang dilaksanakan.

Siklus II juga terdiri dari empat tahapan kegiatan. Pertama perencanaan, beberapa hal yang menjadi rujukan dalam perencanaan pada siklus II adalah Mengkaji hasil dari pelaksanaan siklus I, maka diketahui bahwa pelaksanaan siklus I terjadi peningkatan dari hasil evaluasi belajar dan aktifitas belajar siswa namun masih ditemukan bebrapa kelemahan. Kelemahan ini akan dicermati dan akan dijadikan sebagai bahan pertimbangan dalam perbaikan pada siklus berikutnya yaitu siklus II. Beberapa kelemahan yang ditemukan sebagai hasil refleksi siklus I adalah: 1) Keaktifan siswa masih kurang maksimal, 2) Fokus perhatian siswa masih terbagi dan terbawa model desain pembelajaran lama, 3) Pembelajaran kurang didukung media yang cukup sehingga transfer pengetahuan tentang materi tertentu membuat siswa hanya bisa membayangkan saja tanpa ada media tertentu yang dapat menggambarkan masalah tersebut, 4) Kreativitas siswa belum muncul secara maksimal, siswa cenderung menunggu sesuatu yang dikerjakan (kurang mandiri).

Semua permasalahan yang ditemukan dalam siklus I selanjutnya dicermati dan dilakukan tindakan penanggulangan pada siklus II. Selanjutnya dilakukan rancangan perbaikan tindakan yang akan dilaksanakan dalam siklus II. Adapun perbaikan-perbaikan tersebut adalah sebagai berikut: 1) Siswa dikondisikan agar keterlibatannya maksimal dalam pembelajaran sehingga keaktifannya meningkat dengan strategi dan motivasi yang lebih baik, 2) Siswa dimotivasi dan diberikan agar tetap semangat dan disiplin dalam pembelajaran, 3) Menciptakan kondisi pembelajaran di kelas yang menarik dan menyenangkan lebih banyak berinovasi dalam pembelajaran, 4) Penggunaan media yang relevan dan memfasilitasi penggunaan media sehingga pembelajaran menjadi lebih aktif dan menarik, 5) Guru menyiapkan desain pembelajaran yang lebih menarik dengan membuat LKS sehingga siswa terkondisi untuk aktif dan kreatif, 6) Memberikan kesempatan kepada siswa untuk memanfaatkan waktunya lebih banyak dengan berbagi pengalaman atau pengetahuan dengan teman dalam kegiatan diskusi sehingga secara keseluruhan siswa akan aktif, 7) Siswa lebih banyak diberikan penghargaan untuk meningkatkan 
kepercayaan diri dalam berdiskusi, tanya jawab dan mengerjakan tugas yang dibebankan. Berkaitan dengan hal tersebut maka kegiatan pada perencanaan menyangkut hal sebagai berikut : a) Peneliti menjadualkan kembali kegiatan pembelajaran yang disusun sesuai dengan kalender pendidkan yang ada. Hasil siklus 1 menjadi dasar perbaikan pada pelaksanaan selanjutnya, b) Menyusun RPP yang lebih baik dengan skenario untuk meningkatkan keterlibatan siswa dalam pembelajaran secara maksimal, c) Penyiapan media yang lebih menarik lagi untuk memotivasi belajar siswa, d) Menyususn instrumen penilaian evaluasi dan observasi yang lebih matang untuk memaksimalkan keterlibatan siswa, e) Mendiskusikan hasil dan rancangan skenario pembelajaran bersama guru-guru /teman sejawat. Tahap II yaitu pelaksanaan tindakan, Sesuai dengan perencanaan yang telah disusun pada siklus 2, pelaksanaan pembelajaran dilaksanakan sesuai dengan jadual yaitu meliputi kegiatan : Kegiatan awal yang meliputi apersepsi yang lebih menarikdan pengelolaan kelas secara maksimal, menyiapkan materi ajar secara matang, menjelaskan kegiatan yang akan dilaksanakan sesuai skenario pembelajaran yang telah disusun, mengorganisaikan siswa dalam kelompok belajar untuk berdiskusi, tanya jawab , memfasilitasi kegiatan siswa dengan menyiapkan LKS yang digunakan dalam kerja kelompok untuk melaksanakan pengamatan terhadap materi yang diajarkan di lingkungan sekolah, hasil kerja kelompok didiskusikan dan dielaborasikan dengan kelompok yang lain , memberikan penghargaan terhadap individu dan kelompok yang berhasil , serta pada kegiatan akhir mengadakan evaluasi hasil belajar dengan tes terulis yang sudah disusun. Pada tahap III yaitu observasi hasil dari tindakan yang telah dilaksanakan berupa data hasil belajar yang ditunjukkan dalam bentuk Tabel 2 .

Tabel 2. Hasil Belajar IPA Siswa Kelas IV SD Negeri 1 Ban Siklus II

\begin{tabular}{|c|c|c|c|c|}
\hline $\begin{array}{c}\text { Nomor Subjek } \\
\text { Penelitian }\end{array}$ & NAMA SISWA & NIS & NILAI & KETERANGAN \\
\hline 1 & I Nyoman Reda & 1662 & 75 & Tuntas \\
\hline 2 & Ni Komang Rustiana Dewi & 1726 & 75 & Tuntas \\
\hline 3 & I Ketut Arya Linjong & 1748 & 75 & Tuntas \\
\hline 4 & I Komang Widiantara Putra & 1827 & 75 & Tuntas \\
\hline 5 & I Kadek Wirawan & 1829 & 80 & Tuntas \\
\hline 6 & Ni Wayan Apriyanti & 1830 & 80 & Tuntas \\
\hline 7 & I Komang Alit & 1831 & 65 & Belum Tuntas \\
\hline 8 & I Made Toni Angga Sukma & 1838 & 85 & Tuntas \\
\hline 9 & Pande Kadek Ristayani & 1839 & 90 & Tuntas \\
\hline 10 & Ni luh Susiani & 1840 & 80 & Tuntas \\
\hline 11 & I Komang Ari Sudiarsana & 1842 & 80 & Tuntas \\
\hline 12 & Ni Nengah Julita & 1844 & 80 & Tuntas \\
\hline 13 & Ni Kadek Eva Antari & 1846 & 75 & Tuntas \\
\hline 14 & I Ketut Dedy Rustyawan & 1847 & 75 & Tuntas \\
\hline 15 & I Nengah Putu Yoga Pratama & 1849 & 75 & Tuntas \\
\hline 16 & I Nengah Mario & 1851 & 70 & Tuntas \\
\hline 17 & I Komang Aditya & 1857 & 65 & Belum Tuntas \\
\hline 18 & I Komang Feri Sastrawan & 1859 & 80 & Tuntas \\
\hline 19 & Ni Komang Novi Widiastuti & 1863 & 75 & Tuntas \\
\hline 20 & Ni Luh Era Prasetia & 1864 & 75 & Tuntas \\
\hline 21 & I Komang Ari Kamis & 1868 & 75 & Tuntas \\
\hline 22 & I Nengah Ari Arnawa & 1869 & 70 & Tuntas \\
\hline 23 & Ni Komang Meliani & 1938 & 75 & Tuntas \\
\hline 24 & Ni Komang Erawati & 1796 & 75 & Tuntas \\
\hline 25 & Ni Komang Indrayani & 1798 & 75 & Tuntas \\
\hline 26 & Ni Nyoman Tri Utami & 1812 & 75 & Tuntas \\
\hline 27 & I Made Subawa & 1871 & 75 & Tuntas \\
\hline \multirow[t]{6}{*}{28} & I Wayan Wartana & 1873 & 75 & Tuntas \\
\hline & Jumlah & & 2125 & \\
\hline & Nilai rata-rata & & 75,89 & \\
\hline & Daya Serap & & $75,89 \%$ & \\
\hline & Ketuntasan Klasikal & & $92,86 \%$ & \\
\hline & KKM & & 70,00 & \\
\hline
\end{tabular}


Pada tahap III, yaitu refleksi siklus II, data yang diperoleh selama melaksanakan penelitian merupakan data dari Rata-rata hasil belajar siswa sesuai tabel di atas dihitung dengan menggunakan rumus yang telah ditetapkan. Data tersebut dapat disajikan dalam grafik dibawah ini.

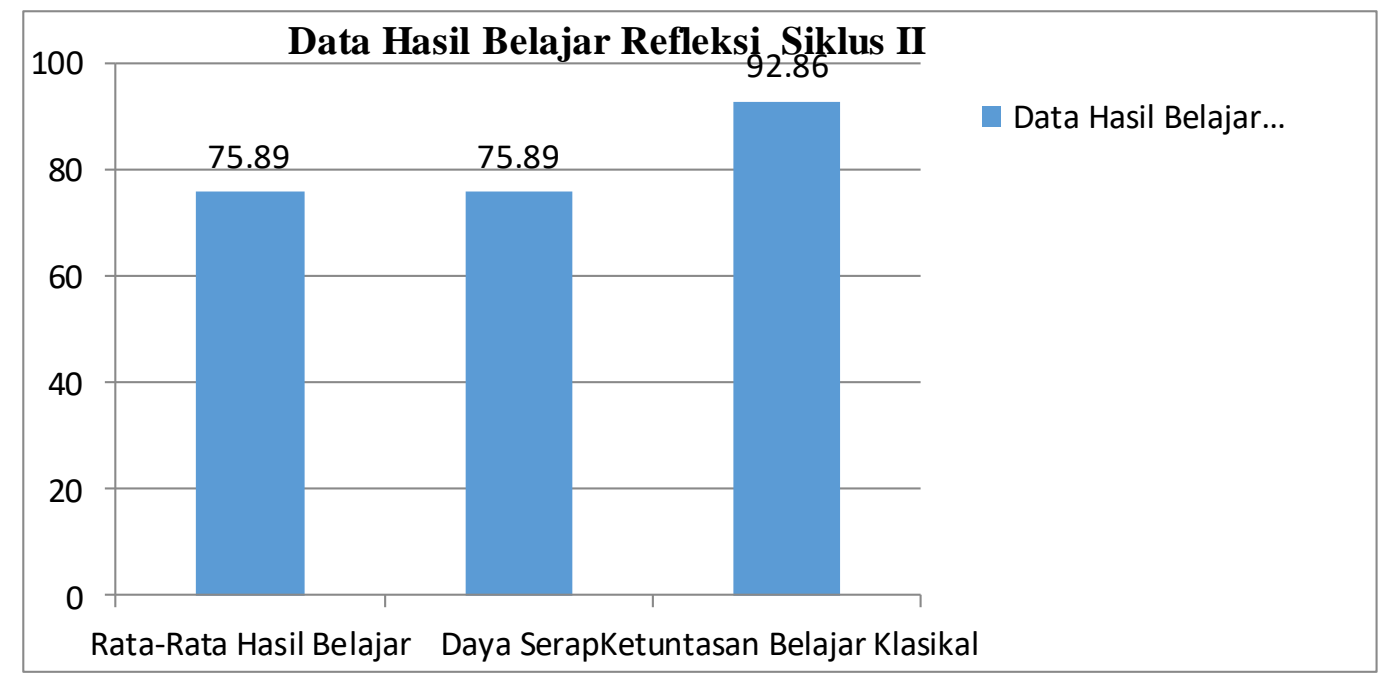

Gambar 3. Grafik Hasil Belajar IPA Siswa Kelas IV SD Negeri 1 Ban Semester I Tahun Pelajaran 2016/2017 Siklus II

Berdasarkan hasil analisis dalam tabel di atas diketahui bahwa secara klasikal siswa kelas IV SD Negeri 1 Ban sudah mampu mencapai bahkan melebihi target KKM yang ditetapkan pada mata pelajaran IPA. Rata-rata hasil belajar klasikal pada siklus II sebesar 75,89. Ini menunjukkan bahwa hasil tersebut telah sesuai dengan KKM yang besarnya 70,00 bahkan lebih tinggi. Daya Serapa sudah mencapai 75,89\%. Pada sisi yang lainnya target ketuntasan belajar secara klasikal sudah sesuai dengan harapan bahkan melampaui dari yang ditettapkan yaitu 92,86 yang ditunjukkan dengan jumlah siswa yang tuntas sebanyak 24 orang dan belum tuntas sebanyak 2 orang.

Tindakan yang dilakukan pada siklus II merupakan penyempurnaan terhadap tindakan pada siklus I. Hal mendasar yang membedakan antara siklus I dengan siklus II adalah adanya bimbingan yang dilakukan dalam siklus II sebagai upaya untuk meningkatkan atau memaksimalkan keterlibatan siswa dalam pembelajaran. Beberapa temuan dalam pelaksanaan tindakan di siklus II antara lain: 1) Secara bertahap motivasi siswa sudah semakin tumbuh sehingga menjadi dasar kesadaran terhadap perannya dalam pembelajaran, 2) Siswa semakin terfokus terhadap pembelajaran degan mencermati dan keterlibatannya dalam setiap langkah yang dilakukan guru dalam pembelajaran, 3) Desain pembelajaran yang menarik dan penggunaan media yang relevan meningkatkan peran dan keatifan siswa, 4) Kreativitas siswa telah tampak dengan keterlibatannya secara maksimal dalam aktivitas pembelajaran. 5) Siswa semakin percaya diri dalam aktifitas belajar siswa seperti diskusi, bertanya, memberi tanggapan,dan mempresentasikan hasil kerja kelompok

Menurut Hamalik (2004:18) belajar adalah suatu proses perubahan tingkahlaku individu melalui interaksi dengan lingkungan Sementara Nurkancana, (1986), menyatakan bahwa hasil belajar adalah hasil yang dicapai seseorang dalam kegiatan belajar mengajar selama kurun waktu tertentu yang dinyatakan dalam bentuk angka atau nilai.

Deskripsi awal menunjukkan sebelum penerapan pembelajaran kontekstual pada mata pelajaran IPA kelas IV SD negeri 1 Ban hasil belajar dan keaktifan siswa masih rendah. Setelah melaksanakan penerapan pembelajaran kontekstual sangat terlihat peningkatan hasil belajar dan keaktifan siswa dalam proses pembelajaran. Mengacu pada hasil dan analisis yang dilakukan pada setiap tahapan yang dilaksanakan, maka dapat ditegaskan bahwa penerapan pembelajaran Kontekstual dapat meningkatkan hasil belajar IPA siswa kelas IV SD Negeri 1 Ban tahun pelajaran 2016/2017. Peningkatan hasil belajar siswa kelas IV SD Negeri 1 Ban tersebut tergambar dari nilai rata-rata, daya serap, dan ketuntasan belajar klasikal yang diperoleh. Menurut Nurkancana, (1986), menyatakan bahwa hasil belajar adalah hasil yang dicapai seseorang dalam kegiatan belajar mengajar selama kurun waktu tertentu yang dinyatakan dalam bentuk angka atau nilai.

Rekapitulasi terhadap keseluruhan nilai tersebut dapat disajikan dalam Tabel berikut: 
Tabel 3. Rekapitulasi Data Hasil Belajar, Daya Serap, dan Ketuntasan Belajar Klasikal IPA Siswa Kelas VI SD Negeri 1 Ban

\begin{tabular}{cclrr}
\hline No & \multicolumn{1}{c}{ Jenis Rekapitulasi Data } & \multicolumn{1}{c}{ Tahapan } & \multicolumn{1}{c}{ Nilai } & Peningkatan \\
\hline 1 & Rata-rata Hasil Belajar & Refleksi Awal & 64,82 & \\
& & Siklus I & 70,00 & 5,18 \\
& \multirow{2}{*}{ Daya Serap } & Siklus II & 75,89 & 5,89 \\
& & Refleksi Awal & $64,82 \%$ & \\
& & Siklus I & $70,00 \%$ & $5,18 \%$ \\
3 & \multirow{2}{*}{ Ketuntasan Belajar Klasikal } & Siklus II & $75,89 \%$ & $5,89, \%$ \\
& & Refleksi Awal & $25 \%$ & \\
& & Siklus I & $53,57 \%$ & $28,57 \%$ \\
& Siklus II & $92,86 \%$ & $39,29 \%$ \\
\hline
\end{tabular}

Berdasarkan tabel rekapitulasi tersebut, maka dapat digambarkan bahwa hasil belajar IPA siwa kelas IV SD Negeri 1 Bantahun pelajaran 2016/2017 mengalami peningkatan baik dari refleksi awal, siklus I hingga siklus II. Peningkatan ini dapat dilihat dari nilai rata-rata hasil belajar yaitu pada refleksi awal sebesar 64,82 (tergolong belum tuntas) menjadi 70,00 pada siklus I (tergolong tuntas) dengan peningkatan sebesar 5,18. Sedangkan pada siklus II mengalami peningkatan sebesar 5,89 menjadi 75,89(tergolong tuntas).

Di samping peningkatan pada hasil belajar, peningkatan juga terjadai pada daya serap dan ketuntasan belajar klasikal. Pada refleksi awal daya serap tercapai sebesar 64,82 selanjutnya pada siklus I meningkat menjadi $70,00 \%$. Hal yang sama juga terjadi pada siklus II dengan daya serap mencapai $75,89 \%$. Sedangkan ketuntasan belajar klasikal pada refleksi awal sebesar $25 \%$ kemudian meningkat menjadi 53,57\% pada siklus I dan menjadi $92,86 \%$ pada siklus II.

Kesimpulan yang didapatkan bahwa pada dasarnya penigkatan-peningkatan hasil belajar tersebut terjadi dikarenakan penerapan pembelajaran kontekstual memberikan manfaat terhadap guru dan siswa dalam pembelajaran IPA. Kelebihan pembelajaran kontekstual sebagai berikut: (1) membantu siswa terlibat secara aktif baik fisik, mental maupun emosional, (2) kegiatan pembelajaran memungkinkan terjadinya komunikasi antara guru dan peserta didik, (3) kegiatan pembelajaran memungkinkan terjadinya interaksi multi arah, (4) kegiatan pembelajaran yang memungkinkan peserta didik memikirkan kembali apa yang telah dilakukan. Hal-hal tersebut di atas merupakan faktor yang berpengaruh sehingga aktivitas pembelajaran dapat dioptimalkan hingga hasil belajar dapat tercapai secara maksimal. Disamping itu, guru juga memiliki peranan yang sangat penting dalam mengelola pembelajaran dengan berinovasi dan berkreasi (membuat LKS) sehingga dapat memaksimalkan situasi pembelajaran.

\section{Simpulan dan Saran}

Simpulan merupakan ringkasan hasil penelitian yang bertalian dengan rumusan masalah dan tujuan penelitian Berdasarkan hasil tindakan penelitian yang dilakukan pada siklus I dan II mulai dari perencanaan, tindakan observasi/pengamatan dan refleksi dapat disampaikan bahwa penerapan pembelajaran kontekstual dapat meningkatkan hasil belajar IPA siswa kelas IV SD Negeri 1 Ban Semester I tahun pelajaran 2016/2017. Peningkatan hasil belajar tersebut dapat dilihat dari perolehan nilai rata-rata, daya serap, dan ketuntasan belajar klasikal. Nilai rata-rata hasil belajar pada refleksi awal sebesar 64,82 (tergolong belum tuntas) menjadi 70,00 pada siklus I (tegolong tuntas) dengan peningkatan sebesar 5,18, dan pada siklus II juga mengalami peningkatan sebesar 5,89 menjadi 75,89(tergolong tuntas). Sejalan peningkatan pada hasil belajar, peningkatan juga terjadi pada daya serap dan ketuntasan belajar klasikal. Pada refleksi awal daya serap tercapai sebesar $64,82 \%$ selanjutnya pada siklus I meningkat menjadi $70,00 \%$. Hal yang sama juga terjadi pada siklus II dengan daya serap mencapai $75,89 \%$. Sedangkan ketuntasan belajar klasikal pada refleksi awal sebesar $25 \%$ kemudian meningkat menjadi $53,57 \%$ pada siklus I dan menjadi $92,86 \%$ pada siklus II.

Berdasarkan hasil penlitian yang telah diperoleh seperti uraian diatas dapat disampaikan beberapa hal sebagai berikut: agar proses belajar mengajar di SD Negeri 1 Ban lebih efektif dan menyenangkan agar memberikan hasil yang lebih optimal lagi pada siswa, kepada guru disarankan agar selalu berupaya berinovasi dalam mendesain pembelajaran sehingga menjadi menarik dan menyenangkan, penerapan pembelajaran kontekstual pada mata pelajaran IPA semestinya menjadi pilihan dari beberapa metode yang ada mengingat metode ini telah terbukti dapat meningkatkan kerjasama, berkreasi, bertindak aktif, bertukar informasi, mengeluarkan pendapat, bertanya, berargumentasi dan cukup efektif dalam meningkatkan hasil belajar siswa, kepada pihak sekolah khususnya kepala sekolah agar memberikan 
motivasi, perhatian dan kesempatan yang luas terhadap guru dalam mengelola pembelajaran secara efektif dengan penerapan berbagai model dan inovasi sehingga pembelajaran menjadi menarik, walaupun penelitian ini sudah dapat membuktikan efek utama dari penerapan model pembelajaran kontekstual dalam meningkatkan hasil belajar, sudah pasti dalam penelitian ini masih ada hal-hal yang belum sempurna dilakukan, oleh karenanya kepada peneliti lain yang berminat meneliti topik yang sama untuk meneliti bagian-bagian yang tidak sempat diteliti dengan kajian yang lebih mendalam.

\section{Daftar Rujukan}

Agung, A.A. Gede. 1997. Metodologi Penelitian Pendidikan. Singaraja: STKIP

Arikunto,Suharsimi dan Cepi Safruddin Abdul Jabar, 2009. Evaluasi Program Pendidikan. Jakarta: Paragonatama Jaya.

Badan Standar Nasional Pendidikan. 2007. Peraturan Menteri Pendidikan Nasional Republik Indonesia Nomor 41 Tahun 2007. Jakarta: BSNP.

Budiningsih, Asri. 2005. Belajar dan Pembelajaran. Jakarta : Rineka Cipta.

Dahar, Ratna Wilis. 1989. Teori-Teori Belajar. Jakarta: Penerbit Erlangga.

Depdiknas Direktorat Jendral Pendidikan Dasar dan Menengah Direktorat Pendidikan Lanjutan Pertama 2002. Pendekatan kontekstual(Contekstual Teaching and Learning). Jakarta.

Djamarah, Saiful Bahri. 2002. Prestasi Belajar dan Kompetensi Guru. Surabaya: Usaha Nasional.

Hamalik, Oemar. 2002. Psikologi Belajar dan Mengajar. Bandung: Sinar Baru.

Hatimah. 2007. Pembelajaran Berwawasan Kemasyarakatan. Jakarta: Universitas Terbuka.

Komalasari, Komkom. 2010. Pembelajaran Kontekstual: Konsep dan Aplikasi. Cetakan ke- 1. Bandung: PT Refika Aditama.

Nurhadi dan Senduk. 2004. Pembelajaran Kontekstual dan Penerapannya dalam KBK. Malang: Universitas Negeri Malang.

Nurkancana, 1986, Evaluasi Pendidikan, Surabaya, Usaha Nasional.

Purwanto, Ngalim,M. 1993 Media Pengajaran. Bandung: Sinar Baru.

Sudiarta, I Wayan. 2009. Upaya Meningkatkan Hasil Belajar Matematika Melalui Penggunaan Model Pembelajaran Kontekstual Pada siswa Kelas VI Semester 1 SD Negeri 1 Sukadana Kecamatan Kubu Tahun Ajaran 2009/2010

Rusyan, A. Tabrani. 1993. Proses Belajar Mengajar yang Efektif Tingkat Pendidikan Dasar. Bandung. Bina Budhaya.

Slameto. 2003. Belajar dan Faktor- Faktor yang Mempengaruhinya, Jakarta: Rineka Cipta.

Sunaryo, 1989. Strategi Belajar Mengajar Ilmu Pengetahuan Sosial. Cet.2Malang: IKIP Malang

Tantra, Dewa Komang, 2004, Strategi Peningkatan Kualitas Pembelajaran, Singaraja: Makalah Pelatihan Guru Khusus ( Pemandu) SD/MI di Kabupaten Karangasem

Sudiarta, I Wayan 2009. Upaya Untuk Meningkatkan Hasil Belajar Matematika Melalui Penggunaan Model Pembelajaran Kontekstual Pada Siswa Kelas VI Semester 1 SD Negeri 2 Sukadana Kecamatan Kubu Tahun Ajaran 2009/2010. Singaraja: Jurusan PGSD Undikhsa Singaraja.

Setyaningrum, Lies. 2013. Pengaruh Model Pembelajaran Kontekstual Terhadap Hasil Belajar Matematika. 
Didaktika Dwija Indria, Volume 1, Nomor 6.

Wardani, I. G. A. K Siti Julaeha. Modul IDIK 4307. Pemantapan Kemampuan Mengajar. Jakarta: Universitas Terbuka.

Yanirawati, Silvia. 2012. Pembelajaran Dengan Pendekatan Kontekstual Disertai Tugas Peta Pikiran Untuk Meningkatkan Kemampuan Koneksi Matematika Siswa. Jurnal Pendidikan Matematika, Vol.1, No.1.

Yulia Dwi Ernawati, 2014 . Peningkatan Prestasi Belajar IPA dengan Menggunakan Model Pembelajaran Contextual Teaching and Learning(CTL) Pada Siswa Kelas Va SD Model Kabupaten Sleman. 